\title{
Los Angeles Basin airborne organic aerosol characterization during CalNex
}

\author{
J. S. Craven, ${ }^{1}$ A. R. Metcalf, ${ }^{2,3}$ R. Bahreini, ${ }^{4,5,6}$ A. Middlebrook, ${ }^{4,5}$ P. L. Hayes, ${ }^{4,7}$ \\ H. T. Duong, ${ }^{8}$ A. Sorooshian, ${ }^{8,9}$ J. L. Jimenez, ${ }^{4,7}$ R. C. Flagan, ${ }^{1,2}$ and J. H. Seinfeld ${ }^{1,2}$ \\ Received 12 March 2013; revised 13 September 2013; accepted 16 September 2013; published 14 October 2013.
}

[1] We report airborne organic aerosol (OA) measurements over Los Angeles carried out in May 2010 as part of the CalNex field campaign. The principal platform for the airborne data reported here was the CIRPAS Twin Otter (TO); airborne data from NOAA WP-3D aircraft and Pasadena CalNex ground-site data acquired during simultaneous TO flybys are also presented. Aerodyne aerosol mass spectrometer measurements constitute the main source of data analyzed. The increase in organic aerosol oxidation from west to east in the basin was sensitive to OA mass loading, with a greater spatial trend in O:C associated with lower mass concentration. Three positive matrix factorization (PMF) components (hydrocarbon-like organic aerosol (HOA), semi-volatile oxidized organic aerosol (SVOOA), and low volatility oxidized organic aerosol (LVOOA)) were resolved for the one flight that exhibited the largest variability in estimated $\mathrm{O}: \mathrm{C}$ ratio. Comparison of the PMF factors with two optical modes of refractory black carbon (rBC)-containing aerosol revealed that the coating of thinly coated $\mathrm{rBC}$-containing aerosol, dominant in the downtown region, is likely composed of HOA, whereas more thickly coated rBC-containing aerosol, dominant in the Banning pass outflow, is composed of SVOOA and LVOOA. The correlation of water-soluble organic mass to oxidized organic aerosol (OOA) is higher in the outflows than in the basin due to the higher mass fraction of OOA/OA in the outflows. By comparison, the average OA concentration over Mexico City MILAGRO (Megacity Initiative: Local and Global Research Observations) campaign was $\sim 7$ times higher than the airborne average during CalNex.

Citation: Craven, J. S., A. R. Metcalf, R. Bahreini, A. Middlebrook, P. L. Hayes, H. T. Duong, A. Sorooshian, J. L. Jimenez, R. C. Flagan, and J. H. Seinfeld (2013), Los Angeles Basin airborne organic aerosol characterization during CalNex, J. Geophys. Res. Atmos., 118, 11,453-11,467, doi:10.1002/jgrd.50853.

Additional supporting information may be found in the online version of this article.

${ }^{1}$ Division of Chemistry and Chemical Engineering, California Institute of Technology, Pasadena, California, USA.

${ }^{2}$ Division of Engineering and Applied Science, California Institute of Technology, Pasadena, California, USA.

${ }^{3}$ Now at the Combustion Research Facility, Sandia National Laboratories, Livermore, California, USA.

${ }^{4}$ Cooperative Institute for Research in Environmental Sciences, University of Colorado Boulder, Boulder, Colorado, USA.

${ }^{5}$ Earth System Research Laboratory, National Oceanic and Atmospheric Administration, Boulder, Colorado, USA.

${ }^{6}$ Now at the Department of Environmental Sciences, University of California, Riverside, California, USA.

${ }^{7}$ Department of Chemistry and Biochemistry, University of Colorado, Boulder, Colorado, USA.

${ }^{8}$ Department of Chemical and Environmental Engineering, University of Arizona, Tucson, Arizona, USA.

${ }^{9}$ Department of Atmospheric Sciences, University of Arizona, Tucson, Arizona, USA.

Corresponding author: J. H. Seinfeld, Division of Chemistry and Chemical Engineering, California Institute of Technology, Pasadena, CA 91125, USA. (seinfeld@caltech.edu)

C2013. American Geophysical Union. All Rights Reserved.

2169-897X/13/10.1002/jgrd.50853

\section{Introduction}

[2] Organic matter contributes substantially to the mass of submicron atmospheric aerosols [Zhang et al., 2007; de Gouw and Jimenez, 2009]. The lifecycle of atmospheric organic aerosol is complex, and continued characterization through laboratory chamber studies, modeling, and field studies is necessary [Jimenez et al., 2009; Rudich et al., 2007]. The 2010 CalNex field campaign (http://www.esrl.noaa.gov/csd/projects/calnex/) was designed to address sources of air pollution and guide airquality regulation in the state of California, as well as address science questions related to climate change [Ryerson et al., 2013]. The Los Angeles Basin has been a historical site for field studies of air pollution, initially motivated by photochemical smog [Haagen-Smit, 1952; Blumenthal et al., 1977]. Air quality in Los Angeles has been steadily improving [Warneke et al., 2012], and the aerosol concentrations measured during CalNex 2010 are among the lowest in the last decade (Figure 1), reflecting the effect of decades of air pollution control in Los Angeles.

[3] The Aerodyne aerosol mass spectrometer (AMS) has emerged as an important analytical tool to characterize the chemical nature of ambient organic aerosol [Jayne 

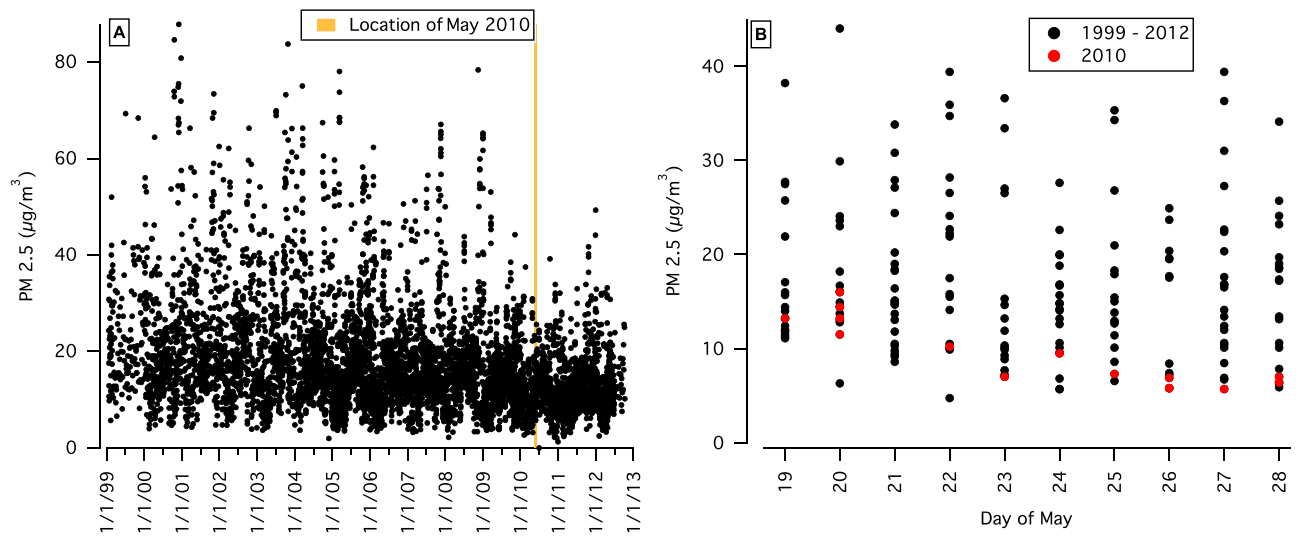

Figure 1. (a) Fourteen years of daily-average PM 2.5 measurements at the Los Angeles-North Main Street $(\mathrm{H})$ CARB monitoring station and (b) the same data shown for the range of days in May measured by the Twin Otter reported here.

et al., 2000; Drewnick et al., 2005; DeCarlo et al., 2006; Canagaratna et al., 2007]. Several recent field campaigns in which organic aerosol (OA) was characterized by the AMS are summarized in Table 1 [Aiken et al., 2009; DeCarlo et al., 2008, 2010; Morgan et al., 2010; Docherty et al., 2008, 2011; Hersey et al., 2011; Hayes et al., 2013]. When combined with measurements of a relatively well conserved particle tracer, such as black carbon, and a source apportionment model, such as Positive Matrix Factorization (PMF) [Paatero and Tapper, 1994], ground- and aircraftbased AMS data can provide useful model constraints on the composition and transport of the organic aerosol (OA) in a region [Zhang et al., 2011]. Additionally, the quantification of the OA oxidation, with AMS O:C atomic ratio, in the ambient atmosphere has become increasingly important with the advent of recent models that utilize $\mathrm{O}: \mathrm{C}$, along with OA mass concentrations and volatility of gas-phase species, to constrain secondary organic aerosol (SOA) formation [Dzepina et al., 2009, 2011; Cappa et al., 2013].

[4] Receptor modeling of OA using PMF analysis of the AMS data can help identify different sources of aerosol mass. When sources are known, PMF factors can elucidate the extent to which the aerosol has undergone atmospheric processing and can separate OA by chemical characteristics such as water solubility, as shown by Kondo et al. [2007], who observed strong correlations between oxidized organic aerosol (OOA) and water-soluble organic carbon (WSOC). For the Los Angeles Basin, AMS PMF is helpful in determining the contribution to organic aerosol from freshly emitted primary versus secondary sources, as well as the extent to which the aerosol is locally produced versus transported regionally. The hydrocarbon-like organic aerosol (HOA) fraction is associated with fresh diesel and gasoline emissions; unit mass resolution AMS PMF results alone are not able to separate the contributions from these sources to OA. Other fresh emissions, such as from biomass burning or cooking, have mass spectra that differ from HOA and can often be separated using PMF. As the aerosol ages in the atmosphere, the AMS-derived OA composition appears less variable, as measured by its increased oxidation state and decreased volatility [Ng et al., 2010; Kroll et al., 2011]. Typically, low volatility oxidized organic aerosol (LVOOA) is achieved after primary volatile and/or semivolatile organic compound emissions have undergone several generations of atmospheric oxidation leading to SOA formation and the aerosol itself has experienced a relatively prolonged period of atmospheric processing.

[5] The focus of the present study is a detailed analysis of the airborne nonrefractory submicron organic aerosol composition in the Los Angeles Basin during the 2010 CalNex field campaign. Questions that will be addressed concerning OA in Los Angeles are the following: (1) How oxidized is Los Angeles OA, and is there a spatial trend of OA oxidation? (2) Can OA PMF factors aid in interpretation of the sources of coating for black-carbon-containing aerosol? (3) Is there a correlation between PMF factors and water-soluble organic mass (WSOM)? (4) To what extent is the airborne OA mass concentration and oxidation consistent with that measured in recent ground-based Los Angeles (LA) area campaigns [Docherty et al., 2011; Hersey et al., 2011; Hayes et al., 2013] as well as in campaigns in Mexico City and Europe [Aiken et al., 2009; DeCarlo et al., 2010; Morgan et al., 2010]?

\section{Airborne and Ground-Based Measurements}

\subsection{Airborne Measurements}

[6] Eighteen research flights were carried out in May 2010 using the Center for Interdisciplinary RemotelyPiloted Aircraft Studies (CIRPAS, Naval Postgraduate School, Monterey, CA, USA) Twin Otter (TO). Description of the complete instrument payload and individual flights of the TO and meteorology of the basin specific to the TO flights during CalNex appears in Duong et al. [2011] and Metcalf et al. [2012]. An evaluation of the application of the Weather Research and Forecasting Model (WRF) to meteorological measurements of Los Angeles made during CalNex is presented elsewhere [Angevine et al., 2012]. The instruments onboard the TO are in an unpressurized cabin and sample from small individual lines that extend from the main inlet, running through the entire length of the aircraft. The air is sampled with a two-stage diffuser inlet designed for the nominal airspeed of the TO $\left(50 \mathrm{~m} \mathrm{~s}^{-1}\right)$ and has no significant loss for aerosol less than $3.5 \mu \mathrm{m}$ diameter [Hegg et al., 2005]. Of the two aerosol mass spectrometers 
CRAVEN ET AL.: LA BASIN AIRBORNE ORGANIC AEROSOL

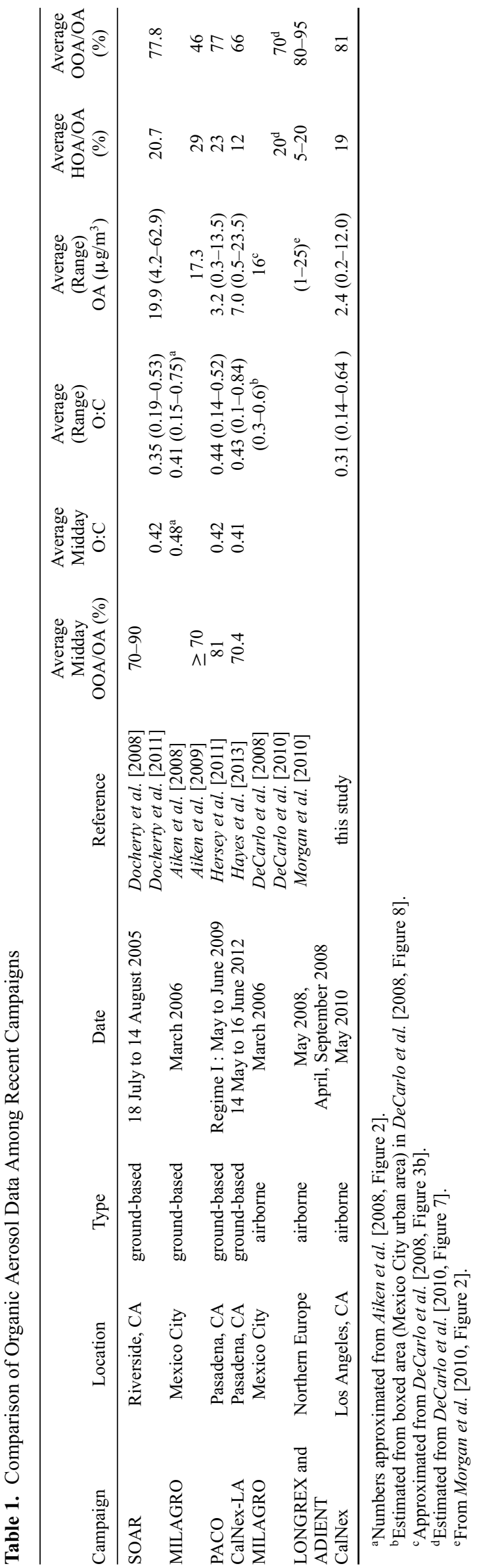

deployed onboard the Twin Otter during CalNex, the University of California, San Diego A-ATOFMS [Cahill et al., 2012] and the Caltech Aerodyne AMS, the AMS was deployed on nine flights, six of which focused on the LA Basin and are the subject of the present study (Table 2). Duong et al. [2011], Metcalf et al. [2012], and Hersey et al. [2013] report the airborne water-soluble organic carbon, refractory black carbon (rBC), rBC coating thickness, hygroscopicity, and aerosol composition and size distribution measurements for the TO flights.

[7] The National Oceanic and Atmospheric Administration (NOAA) P-3 aircraft was deployed during CalNex [Ryerson et al., 2013; Bahreini et al., 2012a, 2012b]; the NOAA AMS average mass spectrum from a coordinated flight path on 19 May 2010 is included in the present analysis.

\subsubsection{Compact Time-of-Flight Aerosol Mass Spectrometer}

[8] Aerodyne compact time-of-flight aerosol mass spectrometers (C-ToF-AMS) [Drewnick et al., 2005; Canagaratna et al., 2007] were deployed to measure submicron aerosol composition onboard both the CIRPAS Twin Otter and NOAA P-3. The C-ToF-AMS sampled at constant pressure (maintained via a pressure-controlled inlet [Bahreini et al., 2008]) through an aerodynamic lens that focuses the aerosols into a beam which is then passed down the particle time-of-flight chamber. Particles ranging $60-600 \mathrm{~nm}$ in vacuum aerodynamic diameter have a $100 \%$ transmission [Jayne et al., 2000]. The effect of the transmission efficiency on measurement of total inorganic mass for both AMS instruments is estimated and discussed in Ensberg et al. [2013]. At the end of the particle time-offlight chamber, the aerosol is vaporized by a $600^{\circ} \mathrm{C}$ heater and ionized with $70 \mathrm{eV}$ electron ionization.

[9] Mass concentrations have been converted to standard temperature and pressure (STP, $273 \mathrm{~K}$ and $1 \mathrm{~atm}$ ) and are reported in units of $\mu \mathrm{g} / \mathrm{sm}^{3}$, micrograms of aerosol per standard cubic meter of air. The data reported are for altitudes below $400 \mathrm{~m}$ above ground level. Analysis of the mass spectra was carried out in the Squirrel ToF toolkit (http://cires.colorado.edu/jimenez-group/ ToFAMSResources/ToFSoftware/index.html) in Igor Pro (WaveMetrics Inc., Lake Oswego, Oregon, USA). Adjustments to the fragmentation table from air interferences were made to the mass spectra based on filter periods taken at the beginning and end of each flight [Allan et al., 2004]. The modifications to the fragmentation table for organic mass at $m / z 18$ and 28 were included [Aiken et al., 2008]. The effect of a change in gas-phase $\mathrm{CO}_{2}$ on the organic aerosol signal at $\mathrm{m} / \mathrm{z} 44$ was investigated for the 19 May P3 flight. The variation in gas-phase $\mathrm{CO}_{2}$ was on the order of 30 ppmv, its contribution to the organic aerosol signal at $m / z 44$ by the AMS was negligible, and so a time-dependent gas-phase $\mathrm{CO}_{2}$ interference correction was not necessary. An aerosol composition-dependent collection efficiency (CE) was applied to all of the data according to the algorithm presented in Middlebrook et al. [2012]. The AMS CE has been shown to be affected by high aerosol acidity and high ammonium nitrate fraction [Middlebrook et al., 2012]; however, for these data, only the high ammonium nitrate fraction heavily influenced the CE values. Empirical correlations presented in Middlebrook et al. [2012], were followed exactly 
CRAVEN ET AL.: LA BASIN AIRBORNE ORGANIC AEROSOL

Table 2. Flight Summary Table

\begin{tabular}{|c|c|c|c|c|c|c|c|}
\hline Date & Day of Week & $\begin{array}{l}\text { Sampling Time } \\
\text { (Local) }\end{array}$ & Region Sampled & $\begin{array}{c}\text { OA Average (SD) } \\
\left(\mu \mathrm{g} / \mathrm{sm}^{3}\right)\end{array}$ & $\begin{array}{l}\text { OA Range } \\
\left(\mu \mathrm{g} / \mathrm{sm}^{3}\right)\end{array}$ & $\begin{array}{l}\text { OA LOD } \\
\left(\mu \mathrm{g} / \mathrm{sm}^{3}\right)\end{array}$ & $\begin{array}{c}\operatorname{Max} B_{(\mathrm{m})}\end{array}$ \\
\hline 19 May & Wednesday & $11: 40-15: 45$ & LA Basin & $6.94(1.59)$ & $(3.12-12.0)$ & 0.328 & 979 \\
\hline 21 May & Friday & $10: 57-15: 05$ & LA Basin, outflow & $2.35(0.621)$ & $(0.733-3.62)$ & 0.150 & 1209 \\
\hline 24 May & Monday & $11: 01-15: 03$ & LA Basin, outflow & $1.72(0.817)$ & $(0.421-4.29)$ & 0.141 & 1749 \\
\hline 25 May & Tuesday & $11: 27-15: 31$ & LA Basin, outflow & $1.03(0.553)$ & $(0.248-3.10)$ & 0.152 & 1519 \\
\hline 27 May & Thursday & $10: 59-14: 45$ & LA Basin & $1.98(0.630)$ & $(0.630-3.79)$ & 0.191 & 1759 \\
\hline 28 May & Friday & $10: 58-15: 03$ & LA Basin & $2.27(0.793)$ & $(0.706-4.45)$ & 0.187 & 1699 \\
\hline
\end{tabular}

${ }^{\mathrm{a}} \mathrm{LOD}=$ limit of detection $=3 \times$ standard deviation of signal during filter periods.

${ }^{\mathrm{b}} \mathrm{BLH}=$ boundary layer height.

for this work. Non-averaged CE values were applied to the data; however, for reference, the average $\mathrm{CE}$ for the entire campaign was $\mathrm{CE}=0.50( \pm 0.09)$. The time resolution of the Twin Otter AMS measurement was either every $10 \mathrm{~s}$ in mass spec (MS) mode or $10 \mathrm{~s}$ of MS mode and $50 \mathrm{~s}$ of particle time-of-flight (PToF) mode every minute. The time resolution of the P-3 AMS was every $5 \mathrm{~s}$ in MS mode and $5 \mathrm{~s}$ in PToF mode.

[10] Strong correlations of the fraction of organic mass at $m / z 44\left(f_{44}\right)$ versus O:C, as measured by HR-ToF-AMS, have been reported for the MILAGRO, SOAR, and CalNex-LA campaigns [Aiken et al., 2008; Docherty et al., 2011; Hayes et al., 2013], although the slope and intercept values of these regressions from different data sets vary. In this work, the $\mathrm{O}: \mathrm{C}$ reported by the $\mathrm{C}-\mathrm{ToF}-\mathrm{AMS}$ is estimated based on the average of the previously reported regressions of $f_{44}$ versus $\mathrm{O}: \mathrm{C}$ atomic ratio. The trend in $\mathrm{O}: \mathrm{C}$ is emphasized in this work, since the absolute value is estimated and may not be as accurate as the relative change in $\mathrm{O}: \mathrm{C}$. The equation used to calculate $\mathrm{O}: \mathrm{C}$ for the $\mathrm{C}-\mathrm{ToF}-\mathrm{AMS}$ data sets is

$$
\mathrm{O}: \mathrm{C}=3.74 \times f_{44}-0.0348
$$

where the organic mass at $\mathrm{m} / \mathrm{z} 44$ is assumed to be predominantly the $\mathrm{CO}_{2}^{+}$ion fragment. For example, for the aerosol sampled at the Pasadena ground-site, the average contribution from $\mathrm{CO}_{2}^{+}$to $m / z 44$ is $95 \%$ [Hayes et al., 2013].

[11] The aerosol volume calculated from the AMS data is in good agreement with the volume as calculated by the differential mobility analyzer (DMA) onboard the Twin Otter (see supporting information). A comparison of the AMS measurements and other mass measurements onboard the NOAA-P3 aircraft is discussed in Bahreini et al. [2012a, 2012b].

2.1.2. Aerosol Volume Measurement

[12] Aerosol size distribution measurements were made on the Twin Otter by a custom-built, scanning differential mobility analyzer (DMA) system. The data inversion is based on Collins et al. [2002]. The electric mobility diameter range for the DMA is 10 to $800 \mathrm{~nm}$, assuming spherical particles. Total aerosol volume is calculated from the inverted size distributions.

\subsubsection{Single-Particle Soot Photometer}

[13] Single-particle refractory black carbon mass and coating thickness measurements were made onboard the Twin Otter [Metcalf et al., 2012] with a Droplet Measurement Technologies Single-Particle Soot Photometer (SP2, DMT, Boulder, CO, USA). The size range for the black carbon mass reported, based on lognormal fits of single-particle size distributions, is $1 \mathrm{~nm}$ to $1 \mu \mathrm{m}$ volume equivalent diameter $\left(d_{v e}\right)$. The leading-edge only (LEO) portion from the scattering signal was used to retrieve the scattering cross section for use in the Mie scattering model [Gao et al., 2007]. The calibration of the $\mathrm{rBC}$ mass has been reanalyzed from Metcalf et al. [2012] following recommendations of Laborde et al. [2012] and Baumgardner et al. [2012]. The assumed $\mathrm{rBC}$ density is $1.8 \mathrm{~g} \mathrm{~cm}^{-3}$, and refractive index is $1.95-0.79 \mathrm{i}$. In this work we report the $\mathrm{rBC}$ coating thickness diameter, which is derived from the LEO fitted scattering signals in the SP2 by fitting a Mie scattering model to the data [Metcalf et al., 2012]. The Mie scattering model assumes a core-and-shell morphology for deriving coating thickness, with the black carbon core size derived from the incandescence signals in the SP2. The optical diameter detection range of purely scattering particles, with a refractive index of $1.5-0 \mathrm{i}$, is $174-420 \mathrm{~nm}\left(d_{v e}\right)$. The detection range of coating thicknesses changes as a function of $\mathrm{BC}$ core size.

\subsubsection{Particle-Into-Liquid Sampler Total Organic Carbon}

[14] Water-soluble organic carbon (WSOC) was collected using a particle-into-liquid sampler (Brechtel Manufacturing Inc.,) coupled to a Total Organic Carbon Analyzer (Sievers Model 800) [Sullivan et al., 2006]. Water-soluble organic mass (WSOM) was estimated from WSOC using a conversion factor of 1.8 [Docherty et al., 2008].

\subsection{Ground-Based Measurements}

[15] Meteorology, gas-phase, and aerosol-phase measurements were made as part of the CalNex campaign at a Supersite on the California Institute of Technology campus in Pasadena, California from 14 May through 16 June 2010. The Pasadena ground-site HR-ToF-AMS organic aerosol [Hayes et al., 2013] and planetary boundary layer (PBL) height measurements are utilized here to provide context for the airborne measurements. The PBL height data were acquired using a Vaisala CL31 ceilometer using a method described previously [Haman et al., 2012].

\section{Results}

\subsection{Airborne OA Mass and Composition Measurements}

[16] Airborne AMS OA mass concentrations measured on the TO ranged from 0.2 to $12 \mu \mathrm{g} / \mathrm{sm}^{3}$ (Figure 2). Table 2 summarizes the OA average, minimum, and maximum mass loadings for each flight, as well as the limit of detection of OA mass. The greatest variation of OA level is between 19 May and the remaining flights. The 19 May flight observed the highest average $\left(6.94 \mu \mathrm{g} / \mathrm{sm}^{3}\right)$ and maximum 

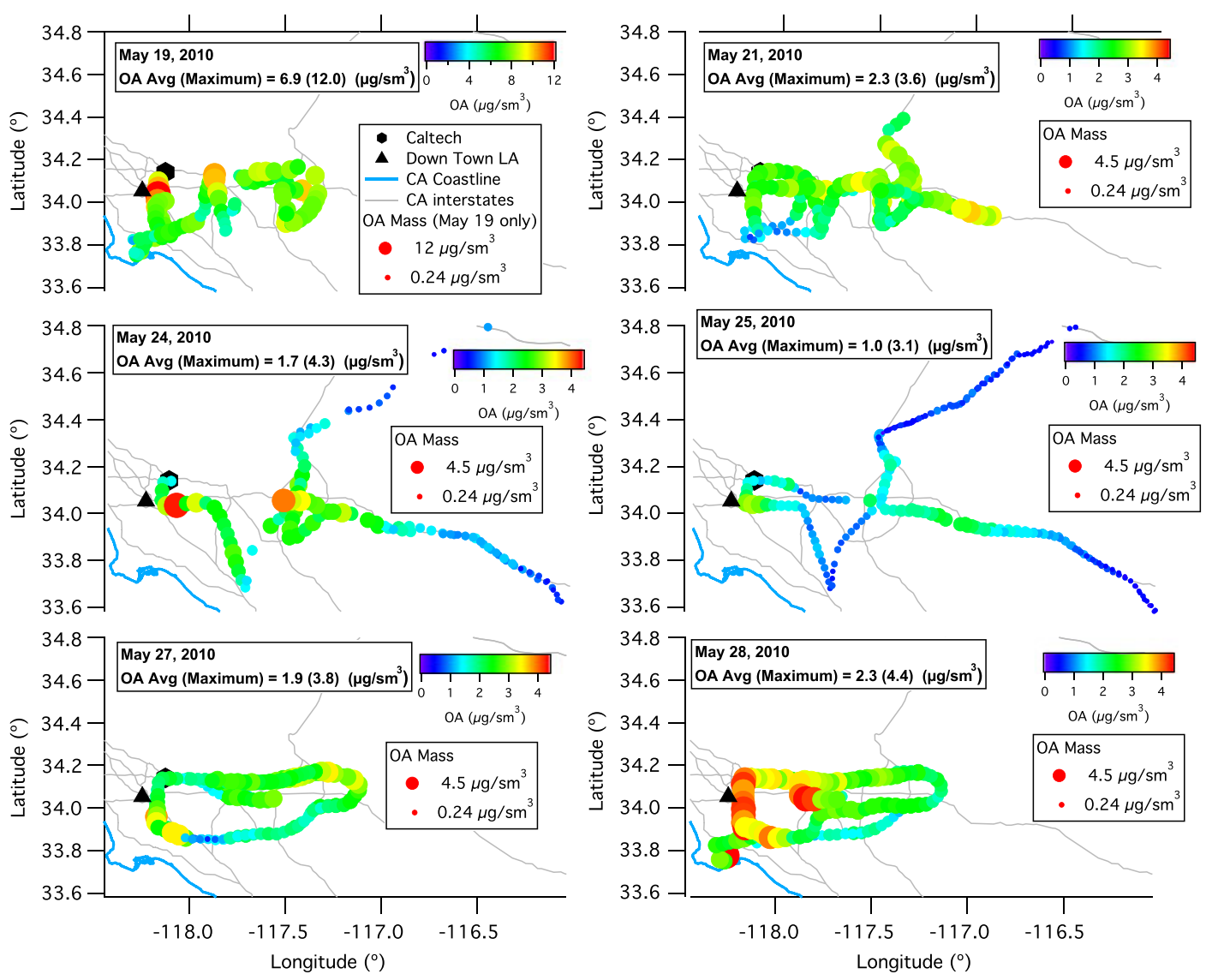

Figure 2. AMS OA mass concentration for each TO flight. Markers are colored and sized according to the mass concentration. The color bar scales are the same except for the 19 May flight, which had higher loadings than the five remaining flights. The Pasadena ground-site at Caltech and downtown Los Angeles are labeled with black hexagon and triangle markers, respectively.

$\left(12.0 \mu \mathrm{g} / \mathrm{sm}^{3}\right)$ mass concentration of the six flights and did not identify a discernible spatial trend within the basin. The 24 May and 25 May flights sampled both the basin and its outflows. The OA mass concentrations in the basin are similar to that sampled immediately above the Banning pass, after which the mass concentration decreases (in both the Banning and El Cajon passes) due to dilution of a polluted air mass into a cleaner air mass.

[17] The atomic O:C ratio of the OA (Figure 3, shown as the marker color) for 19, 21, and 25 May is relatively high in the southwestern basin, near Long Beach. Back trajectory analysis shows that the oxidized aerosol mass in this region of the basin originates from an aged air mass that was transported up the coast [Ensberg et al., 2013]. The relatively high O:C in this region was not observed on 28 May. On 21, 24 , and 25 May OA in the airborne outflow regions exhibited a higher $\mathrm{O}: \mathrm{C}$ than in the basin, indicative of photochemical processing and dilution in the outflows.

[18] To determine the extent to which an increase in $\mathrm{O}: \mathrm{C}$ exists from west to east in the basin, $\mathrm{O}: \mathrm{C}$ is plotted against longitude, to which a linear fit is applied (Figure S7). The results of the fit vary, depending on the flight. The slopes and uncertainties on the slope for each flight's regression line are shown in Figure 4. There was no significant trend in $\mathrm{O}: \mathrm{C}$ from west to east within the basin on 19 May (slope of 0.005 $\Delta \mathrm{O}: \mathrm{C} / \Delta^{\circ}$ longitude on Figure 4$)$. The highest average mass loadings were observed on this day, and the lack of spatial variability in $\mathrm{O}: \mathrm{C}$ could be the result of a relatively wellmixed basin air mass of fresh and aged emissions. Also, this flight had the latest takeoff time, 11:40 local time, which was 40 min later than most of the other flights and had the lowest daily maximum planetary boundary layer height $(979 \mathrm{~m})$. Emissions would have had more time to oxidize, decreasing some of the variability in the fresh emissions measured. On 21, 24, and 28 May, the slopes of the O:C versus longitude were $\sim 0.05 \Delta \mathrm{O}: \mathrm{C} / \Delta^{\circ}$ longitude. On 21 May, high $\mathrm{O}: \mathrm{C}(0.50-0.55)$ was present in the southwestern basin, as well as in the outflows, whereas over the downtown LA region and Pasadena ground-site, the $\mathrm{O}: \mathrm{C}$ was slightly lower $(\sim 0.30)$. On 24 May, the $\mathrm{O}: \mathrm{C}$ is relatively low again in downtown LA region and Pasadena ground-site $(0.25-0.3)$ and then increases slightly to $\sim 0.35$ in the eastern basin and in the outflows. If only the data in the basin are considered, the slope for the 24 May flight is much higher (0.17 $\Delta \mathrm{O}: \mathrm{C} / \Delta^{\circ}$ longitude, Figure S7). The day 24 May was preceded by a day with an anomalously high boundary layer in which the emissions in the basin would have experienced relatively large amount of dilution (Figure 5a). Thus, the 24 May basin and outflow trend could reflect the single day $\mathrm{O}: \mathrm{C}$ trend for SOA formation, rather than from multiday pollution buildup. On $28 \mathrm{May}$, the OA in the western part of the basin has a low O:C (close to 0.20), likely 

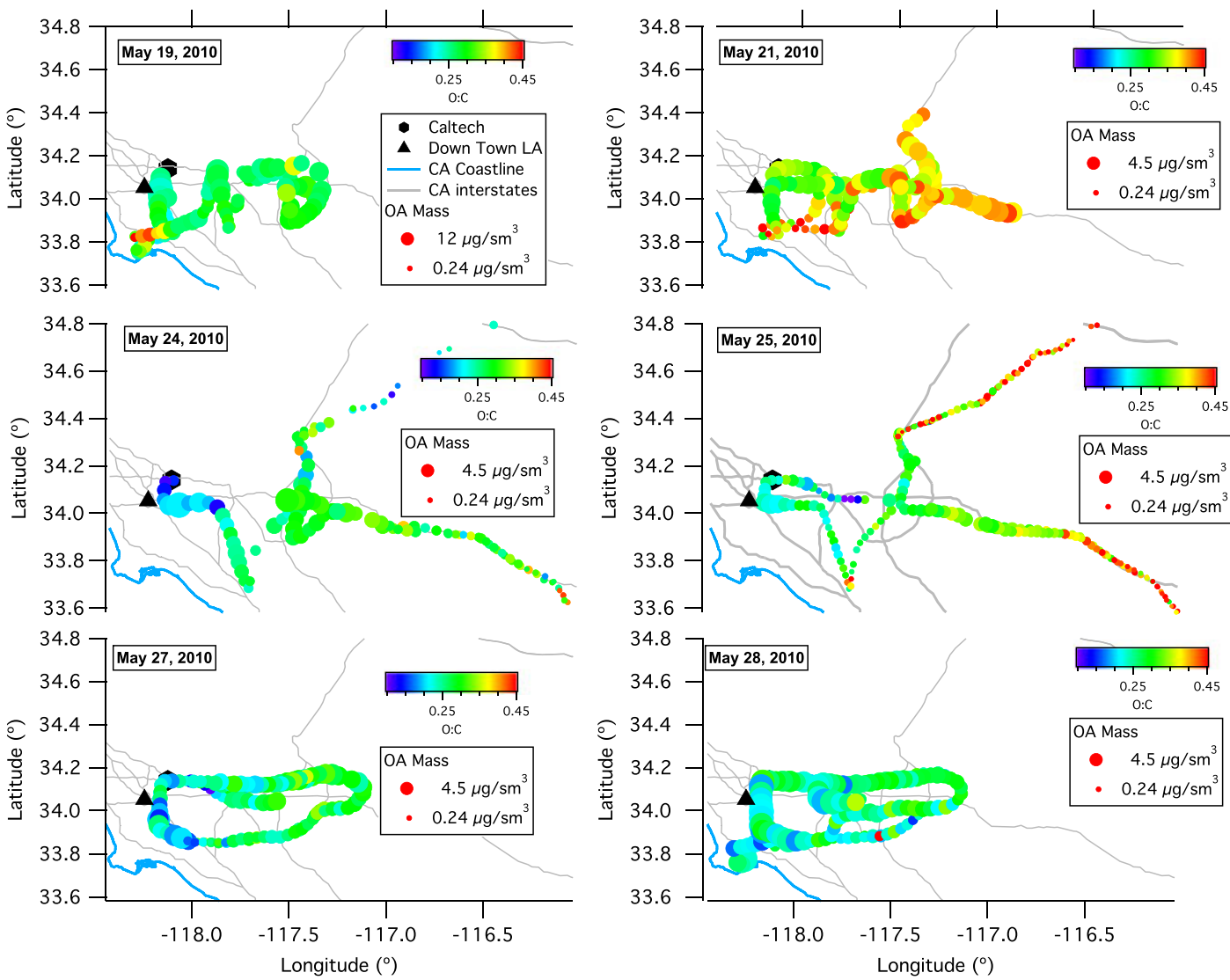

Figure 3. O:C for each TO flight. Markers are colored by O:C and sized according to the mass loading. The color bar scales are the same for all of the flights. The marker size scale is distinct for 19 May, which had higher loadings than the five remaining flights. The Pasadena ground-site at Caltech and downtown Los Angeles are labeled with black hexagon and triangle markers, respectively.

due to fresh mobile emissions from the 710 freeway or Port of Long Beach, and then the $\mathrm{O}: \mathrm{C}$ increases only slightly in the eastern basin. The 25 and 27 May flights found slopes of $\sim 0.10 \Delta \mathrm{O}: \mathrm{C} / \Delta^{\circ}$ longitude (Figure 4). The day 25 May exhibited the largest increase in $\mathrm{O}: \mathrm{C}$ from west to east for an entire flight. This also was the flight with the lowest average mass concentration $\left(1.03 \mu \mathrm{g} / \mathrm{sm}^{3}\right)$. Compared to 24 May, which had the same flight path as 25 May, O:C in the southern part of the basin, as well as in the outflows, exhibited a higher O:C. The increase in O:C between 24 and 25 May is likely a result of the fact that the basin contents and outflow sampled on 25 May represented a combination of aged emissions from 24 May and fresh emissions from 25 May. The difference in slope of increase in $\mathrm{O}: \mathrm{C}$ from west to east appears to be anticorrelated with the flight-averaged mass concentration (green markers in Figure 4), making the O:C spatial variability sensitive to organic mass concentration.

\subsection{Airborne and Ground-Based AMS OA Mass Loading and Spectrum Comparison}

[19] Airborne AMS OA mass loadings, OA/Sulfate ratio, $\mathrm{O}: \mathrm{C}$, and altitude are compared with the Pasadena groundsite AMS and PBLH measurements over the duration of the CalNex-LA campaign in Figure 5. The right-hand side of Figure 5 shows the airborne and ground AMS OA mass loadings, OA/Sulfate ratio, and $\mathrm{O}: \mathrm{C}$ averages during the flyover times only. The TO flights during which the AMS was onboard took place on days with relatively high maximum boundary layer heights, as evidenced as well by relatively low Pasadena ground-site AMS OA mass concentration, when compared to the entire Pasadena ground-site campaign

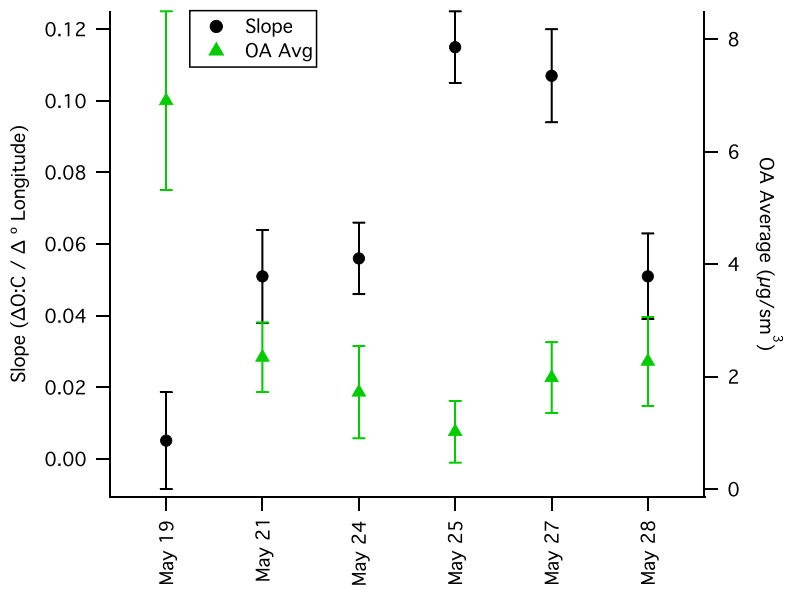

Figure 4. The slope and slope uncertainty from the linear regression of $\mathrm{O}: \mathrm{C}$ versus longitude for each flight are shown with black markers and error bars. The average and standard deviation of OA mass concentration are shown with green markers and error bars for each flight. 


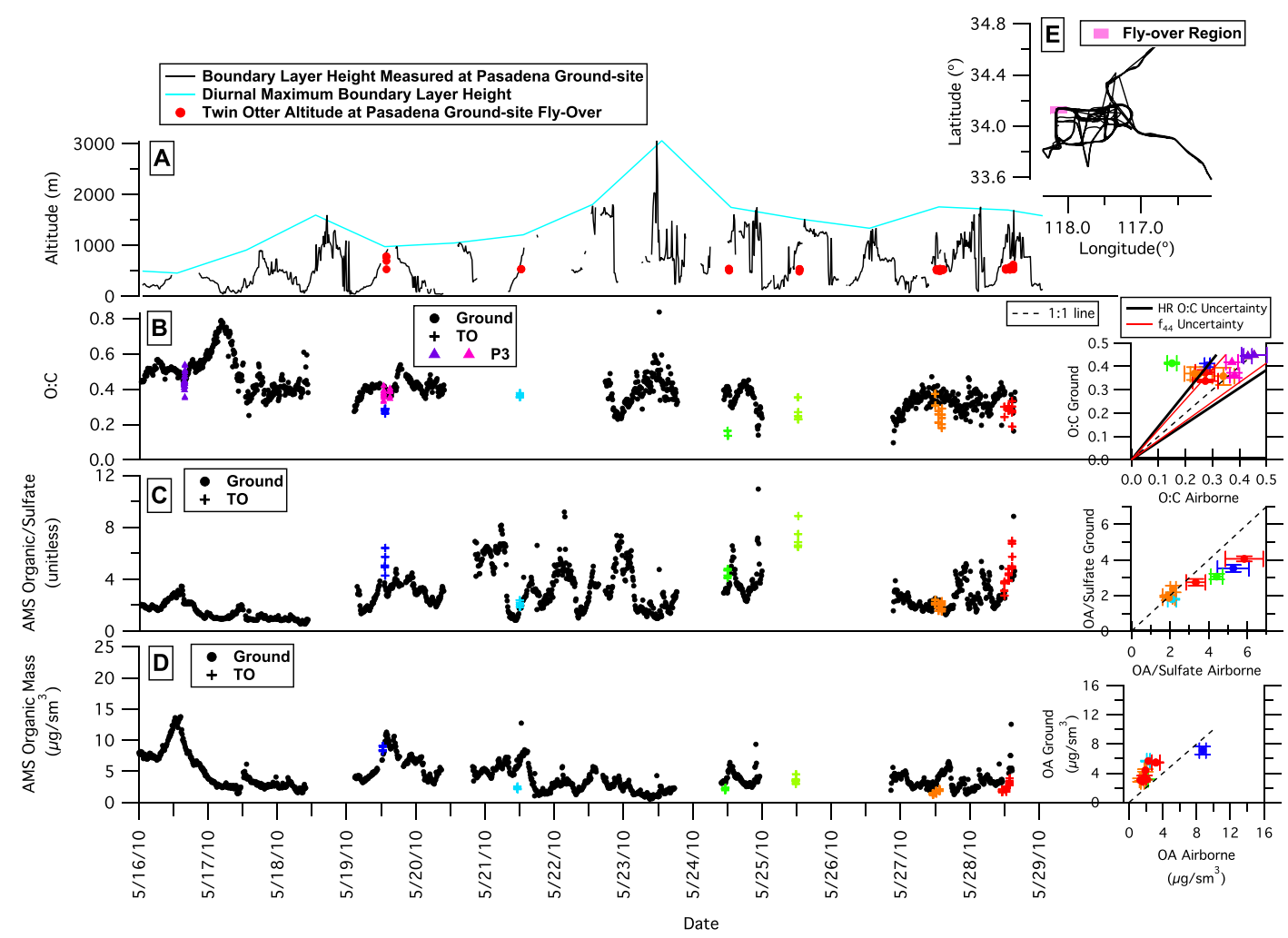

Figure 5. (a) PBLH measurements from the Pasadena ground-site and Twin Otter altitude (red markers) during flyovers versus time. (b) Ground (black markers) and airborne flyover only (colored markers, plus symbol for TO and triangle for P3) O:C versus time. (c) Ground (black markers) and airborne flyover only (colored markers) AMS organic/sulfate versus time. (d) Ground (black markers) and airborne flyover only (colored markers) AMS organic mass concentration versus time. (e) Flyover region is highlighted by pink rectangle.

(Figures 5a and 5d). During the Pasadena ground-site flyovers (flyover location given in Figure 5e), the aircraft was sampling within the boundary layer (Figure 5a). AMS measurements on five of the six flights for which the AMS was onboard are compared to the ground-site AMS OA measurements (25 May 2010 ground-site AMS measurements were not available for comparison). The ground-site OA mass concentrations exceed those measured aloft, except for the 19 May 2010 flyover. The average ratio of OA airborne : OA ground is 0.61 . The ratio between the airborne and ground OA mass concentration is close to that reported for Mexico City MILAGRO for which the airborne OA measurements were $74 \%$ of those measured at the ground-site for a noon to $6 \mathrm{pm}$ local time average [DeCarlo et al., 2008]. The OA/sulfate ratio is in good agreement between the airborne and ground samples. The $\mathrm{O}: \mathrm{C}$ of the airborne samples is slightly lower than the ground measurements, which is consistent with less aged OA. The differences between the two data sets are mostly less than the uncertainty, however. The O:C elemental analysis has an uncertainty of $\pm 30 \%$ [Aiken et al., 2007], and there is additional uncertainty in the determination of $f_{44}$ (see below).

[20] The TO and NOAA P3 flew a coordinated flight path in the basin on 19 May. The flight map of the locations of the two instruments is shown in Figure S8. The average mass spectrum for each instrument and the difference between the two spectra are shown in Figure 6. The largest difference between the two spectra is in $\mathrm{m} / z$ 44. The TO $f_{44}$ is slightly lower, by about $20 \%$ of the $\mathrm{P} 3 f_{44}$. This provides a measure of uncertainty on the $f_{44}$ measurement. The dominant $\mathrm{m} / \mathrm{z}$ 's are labeled and strongly resemble a mixture of aerosol resulting from hydrocarbon combustion (high $m / z 27, m / z 29, m / z 41$, $\mathrm{m} / \mathrm{z} 43, \mathrm{~m} / \mathrm{z} 55, \mathrm{~m} / \mathrm{z} 57, \mathrm{~m} / \mathrm{z} 69$, and $\mathrm{m} / \mathrm{z} 91)$ and atmospheric oxidation (high $m / z 44$ ).

\subsection{Components of the Los Angeles Organic Aerosol}

[21] Positive matrix factorization (PMF) has been widely used as a tool to identify the components of organic aerosol [Lanz et al., 2007; Ulbrich et al., 2009; Aiken et al., 2008, 2009; DeCarlo et al., 2010; Morgan et al., 2010; Zhang et al., 2011; Docherty et al., 2011; Hersey et al., 2011; $\mathrm{Ng}$ et al., 2011; Brown et al., 2012]. In the present work, application of PMF was used to identify the mixture of fresh and aged OA in the basin and outflows. The Twin Otter AMS data were evaluated using the PMF Evaluation Tool (PET) (http://tinyurl.com/PMF-guide) [Ulbrich et al., 2009]. See supporting information for details regarding the solution.

[22] PMF analysis of the data obtained on 25 May, during which the largest variation in $\mathrm{O}: \mathrm{C}$ versus longitude was observed, resolved HOA, SVOOA, and LVOOA factor (Figure 7). The HOA factor is highest in the western basin, due to proximity to fresh emission sources, such as refineries, the Port of Long Beach, and the concentrated motor vehicle traffic associated with downtown LA (Figure 8a). 
CRAVEN ET AL.: LA BASIN AIRBORNE ORGANIC AEROSOL

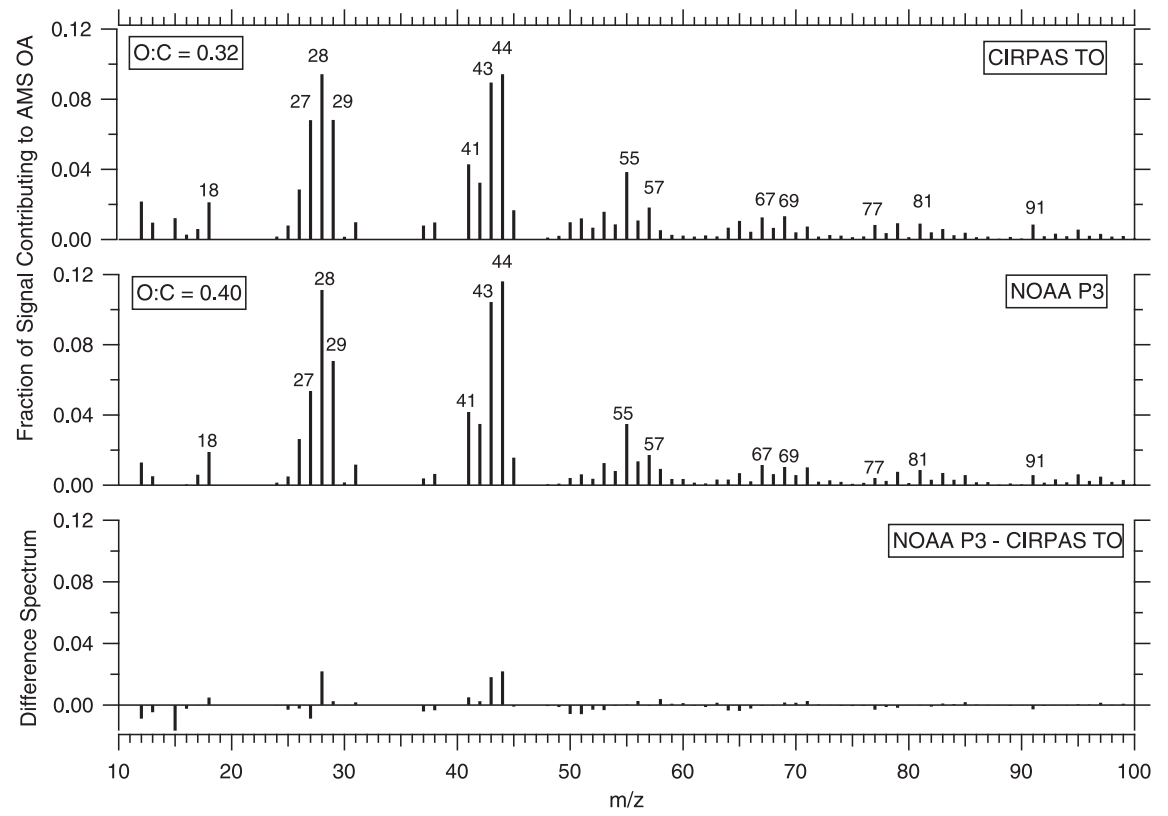

Figure 6. Average AMS mass spectra during the 19 May 2010 intercomparison flight for the CIRPAS TO and NOAA P3. The difference spectrum appears in the bottom panel.

The average mass fraction of $\mathrm{HOA} / \mathrm{OA}$ for the entire flight is 0.19 . The HOA/OA mass fraction is higher when only the basin is considered (0.27) and lower when only the outflows are considered $(0.15)$. Formation of SOA from volatile, semivolatile, and intermediate volatility species is expected to proceed substantially in a few hours at typical summer OH concentrations [Robinson et al., 2007] and can continue even for multiple days [Dzepina et al., 2011]. All of the TO flights considered here occurred midday, so the morning rush-hour emissions (diesel and gasoline) would have undergone a period of oxidation. Late morning and afternoon air samples would contain substantial fractions of both POA and SOA. The OA in the basin is dominated by OOA, which has a mass fraction of 0.73 , in which SVOOA/OA is 0.55

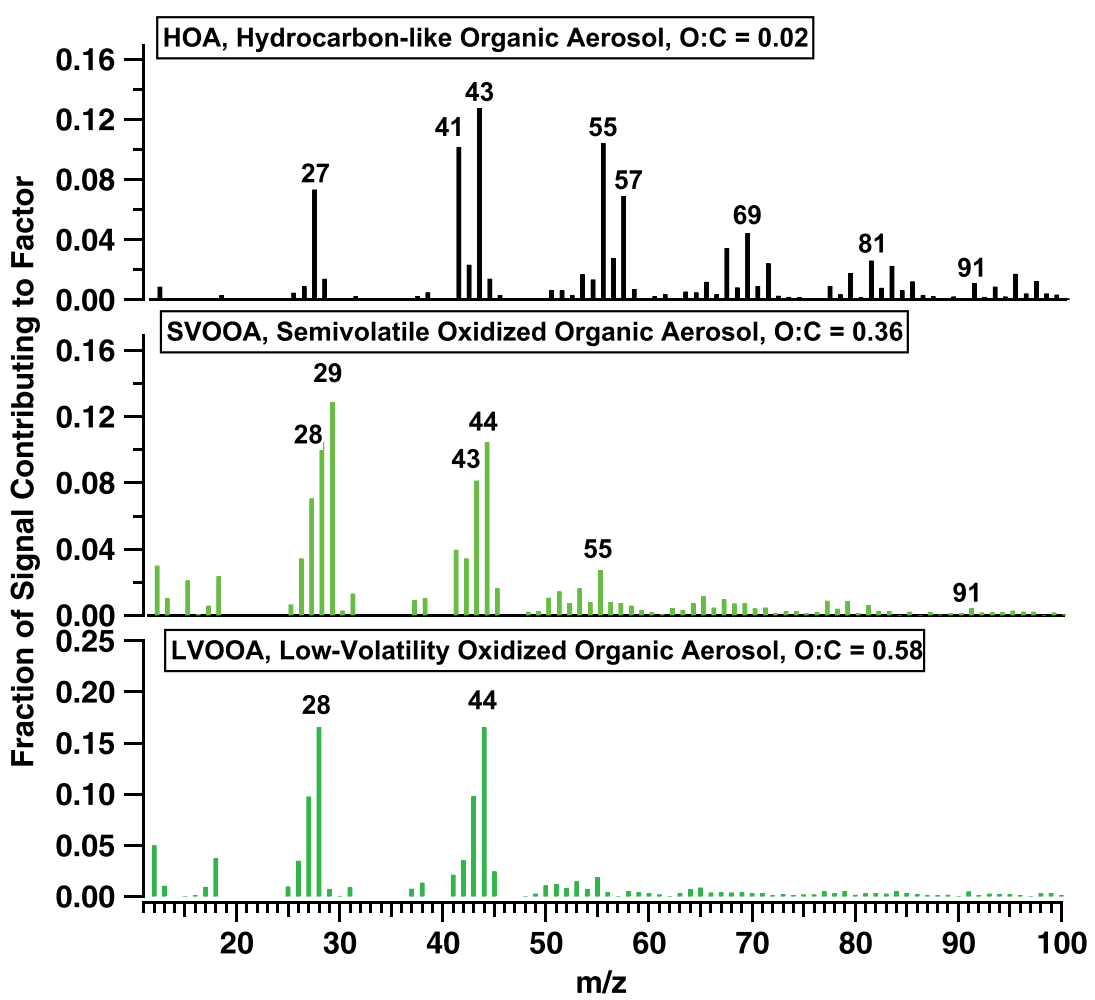

Figure 7. Airborne HOA, SVOOA, and LVOOA factor mass spectral profiles for 25 May. 

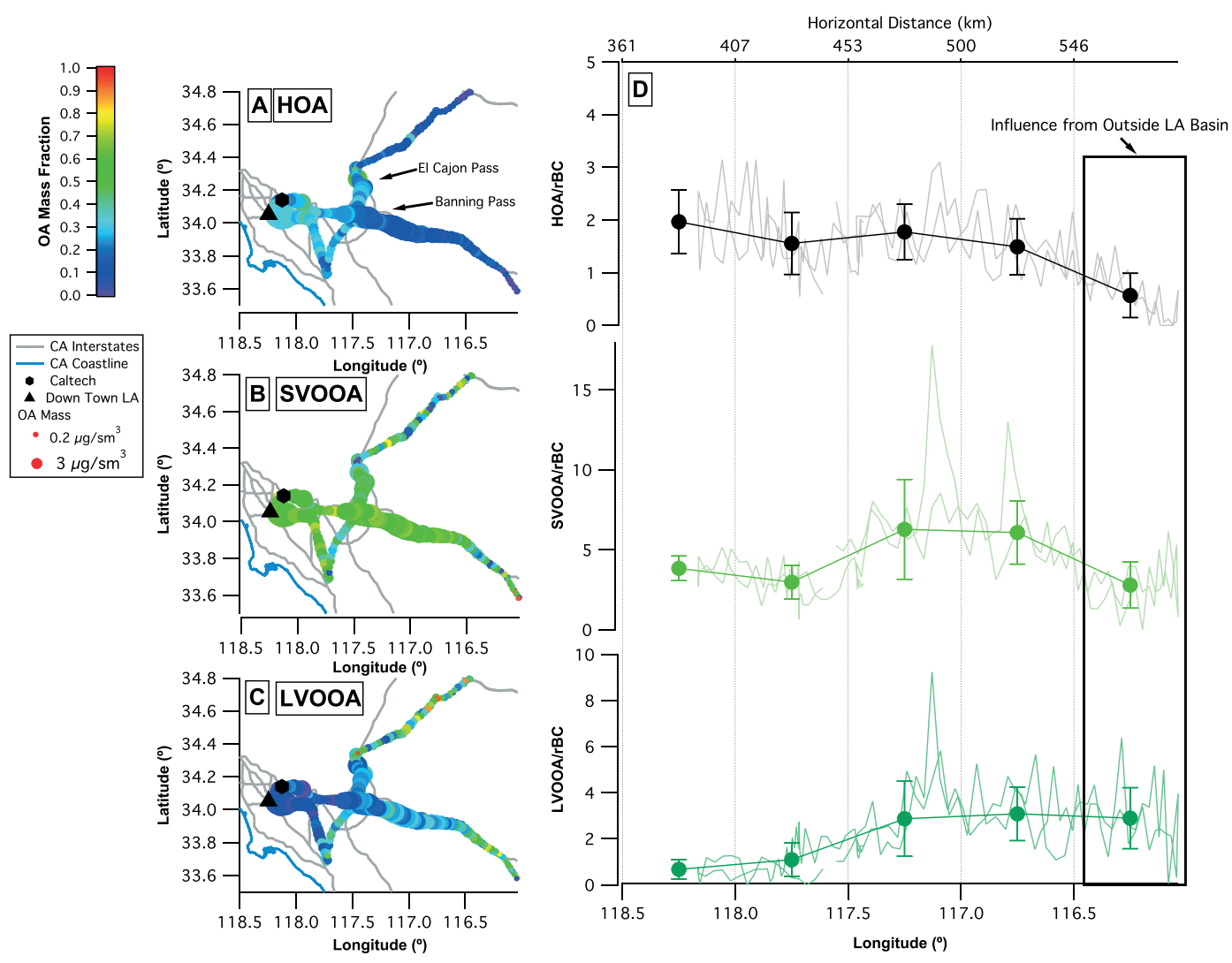

Figure 8. The mass fraction of (a) HOA, (b) SVOOA, and (c) LVOOA for 25 May. Markers are sized by OA mass loading and colored by mass fraction. (d) The $\mathrm{rBC}$ normalized factors are shown versus longitude (bottom axis) and horizontal distance (top axis) according to the Universal Transverse Mercator coordinate system, holding latitude at $34^{\circ} \mathrm{N}$, for the basin and Banning pass data. Data to the east of the Banning Pass outflow were influenced by air from the south and are boxed. The data have been averaged into $0.5^{\circ}$ longitude bins, and both the average and standard deviation (error bars) are shown. The raw data are also displayed to emphasize the variability of the data, especially for the SVOOA and LVOOA normalized factors in the eastern basin and outflows.

and LVOOA/OA is 0.18 . The amount of OOA, specifically SVOOA, is also high for the ground-site PMF results in the 11:00-16:00 (local time) time range [Hayes et al., 2013]. The OOA/OA mass fraction in the outflows, 0.85 , is higher than that in the basin. The SVOOA/OA and LVOOA/OA is 0.43 and 0.42 in the outflows. The flight average OOA/OA, which includes the basin and outflows, is 0.81 (SVOOA/OA flight average is 0.44 and LVOOA/OA flight average is 0.37 , Figures $8 \mathrm{~b}$ and $8 \mathrm{c}$ ).

[23] In lieu of gas-phase $\mathrm{CO}, \mathrm{rBC}$ is used as a tracer for fresh emissions. Figure $8 \mathrm{~d}$ shows the ratio of $\mathrm{HOA} / \mathrm{rBC}$, SVOOA/rBC, and LVOOA $/ \mathrm{rBC}$ from the basin and the Banning Pass data only. The data have been averaged into $0.5^{\circ}$ longitude bins to better quantify the trend in oxidation from west to east. Four-hour and $12 \mathrm{~h}$ back trajectory analysis confirms that the air sampled in the El Cajon and Banning passes originated primarily in the basin [Metcalf et al., 2012; Ensberg et al., 2013]. The data downwind of Banning Pass and east of longitude -116.5 exhibited influence from southernly air masses and not from the Banning Pass. This indicates that the air sampled here did not originate from the basin. These data are highlighted in Figure 8d. The west-to-east trend for $\mathrm{HOA} / \mathrm{rBC}$ is essentially flat with perhaps a small decrease; this behavior is expected since the HOA factor represents primary OA that is likely coemitted with black carbon. The ratio of $\mathrm{SVOOA} / \mathrm{rBC}$ is higher than $\mathrm{HOA} / \mathrm{rBC}$ and LVOOA/rBC, indicating most of the $\mathrm{OA}$ in the 11:00-16:00 time frame is processed, oxidized aerosol but not of exceptionally low volatility. SVOOA/rBC increases in the northeastern part of the basin and into the outflows by approximately $58 \%$ (Table 3 ). $\mathrm{LVOOA} / \mathrm{rBC}$ is smallest in the basin, which implies that during midday, most of the OOA in the basin is not the result of long-range transport or lengthy photooxidation. The LVOOA/rBC ratio steadily increases from west to east by $355 \%$ (Table 3 ).

[24] From the daily averages in Figure 1, 25 May 2010 was characterized by one of the lowest PM 2.5 mass concentrations, not only in May 2010 but also for May in the years 1999-2012. The current data nonetheless highlight the potential for SOA formation even under low pollution conditions, perhaps from a single day of megacity emissions.

\subsection{Oxygenated Organic Aerosol and Water-Soluble Organic Mass in the Basin Versus the Outflows}

[25] Here we discuss the correlations of the organic aerosol components from PMF with WSOM and compare the results between the data collected in the basin and in the outflows. Figure 9 summarizes the correlations of the OA 
Table 3. rBC Normalized Oxidized Factors

\begin{tabular}{lccc}
\hline Normalized OOA Type & $\begin{array}{c}\text { Average (SD, SE) for } \\
118.5-118.0^{\mathrm{a}}\end{array}$ & $\begin{array}{c}\text { Average (SD, SE) for } \\
117.0-116.5^{\mathrm{a}}\end{array}$ & \% Change \\
\hline SVOOA/rBC & $3.84(0.77,0.22)$ & $6.07(1.98,37)$ & 58.0 \\
LVOOA/rBC & $0.67(0.42,0.12)$ & $3.08(1.16,0.22)$ & 354.7 \\
\hline
\end{tabular}

${ }^{\mathrm{a}}$ Longitude.

components with the WSOM from basin and outflow separately from the 25 May flight. Also shown is the correlation of HOA versus OOA (SVOOA + LVOOA) $(r=0.77$ and $r=$ 0.80 ). The high correlation between HOA and OOA likely exists because the two components were sampled from a relatively well-mixed air mass, such as in the region downwind of downtown LA, in which high levels of both HOA and SVOOA were observed. In the outflow region, a correlation between all components is expected since the plume from LA plume is diluting with distance from the basin. Keeping that in mind, a high correlation between one of the components of OA and WSOM may exist due to mixing. OOA and WSOM have a high correlation in the outflows $(r=0.88$ and slope $=1.03 \pm 0.05)$. This correlation is close to that reported by Kondo et al. [2007] for Tokyo, who found that OOA and WSOC were correlated with $r^{2}$ values between 0.77 and 0.91 . The OA versus WSOM in the outflows has a similar correlation $(r=0.87$ and slope $=1.21 \pm 0.05)$ as that of the OOA, but the slope is higher than 1:1. Also, it is not expected that HOA would contribute substantially to WSOM. The correlation of SVOOA to WSOM $(r=0.86)$ in the outflows is higher than that of HOA to WSOM $(r=0.73)$.

[26] The correlation between OOA and WSOM in the basin is lower than in the outflows $(r=0.69$ and slope $=$ $0.41 \pm 0.03)$. When only the correlation of SVOOA versus WSOM in the basin is considered, $r=0.78$ and slope $=$ $0.42 \pm 0.02$, the $r$ value increases compared to the correlation of OOA with WSOM. The change in slope of the regression between SVOOA and WSOM compared to that of OOA is minor, since the concentration of LVOOA in the basin is below $0.5 \mu \mathrm{g} / \mathrm{sm}^{3}$. No correlation between LVOOA with WSOM exists in the basin primarily because the mass concentration is so small. The correlation and slope between HOA and WSOM in the basin $(r=0.69$ and slope $=$ $0.18 \pm 0.01)$ is lower than that between SVOOA and WSOM. The correlation for HOA versus WSOM reported here is higher than the correlation of HOA versus WSOC reported by Kondo et al. [2007] $\left(r^{2}=0.22-0.23\right)$, likely because the aircraft sampled relatively well-mixed air masses in polluted regions.

[27] The OOA in the outflows comprises a significant mass fraction of LVOOA, which might explain the higher correlation with WSOM [Duong et al., 2011]. The OOA in the basin comprises a high mass fraction of SVOOA and a weaker correlation with WSOM. This could indicate that some of the freshly formed SOA in the LA Basin is less water soluble.

\subsection{Composition of Aerosol Coating Thickness of rBC-Containing Particles}

[28] Within the SP2 detection limits, only a small fraction of optically detected particles also contain detectable black carbon. For 25 May the average fraction was 0.08. Metcalf et al. [2012] observed two different modes of black carbon
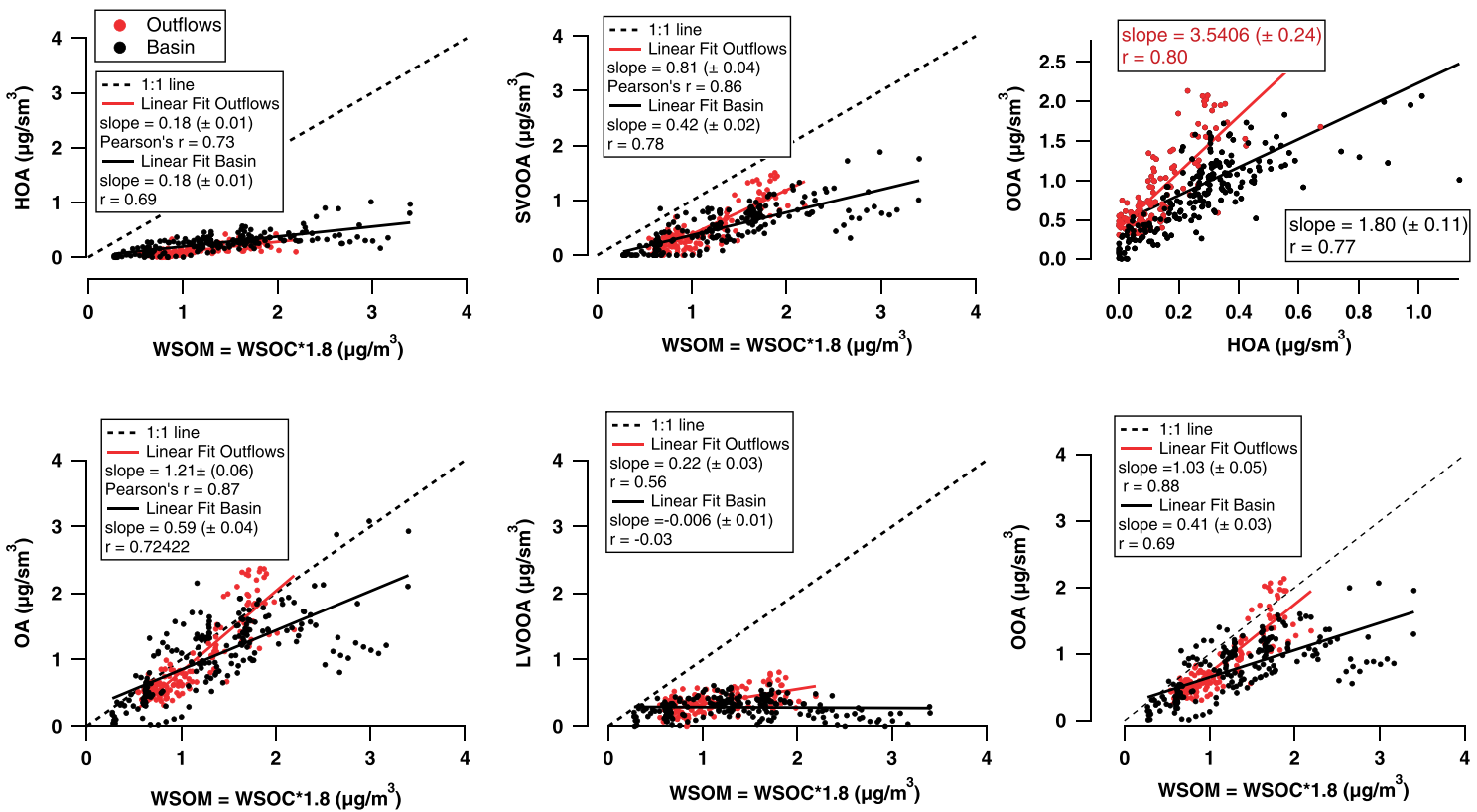

Figure 9. Correlation of OA, HOA, SVOOA, LVOOA, and OOA (SVOOA + LVOOA) versus WSOM and the correlation of HOA with OOA. The best fit line, $r$, and slope for the basin (black) outflow (red) are also shown. 

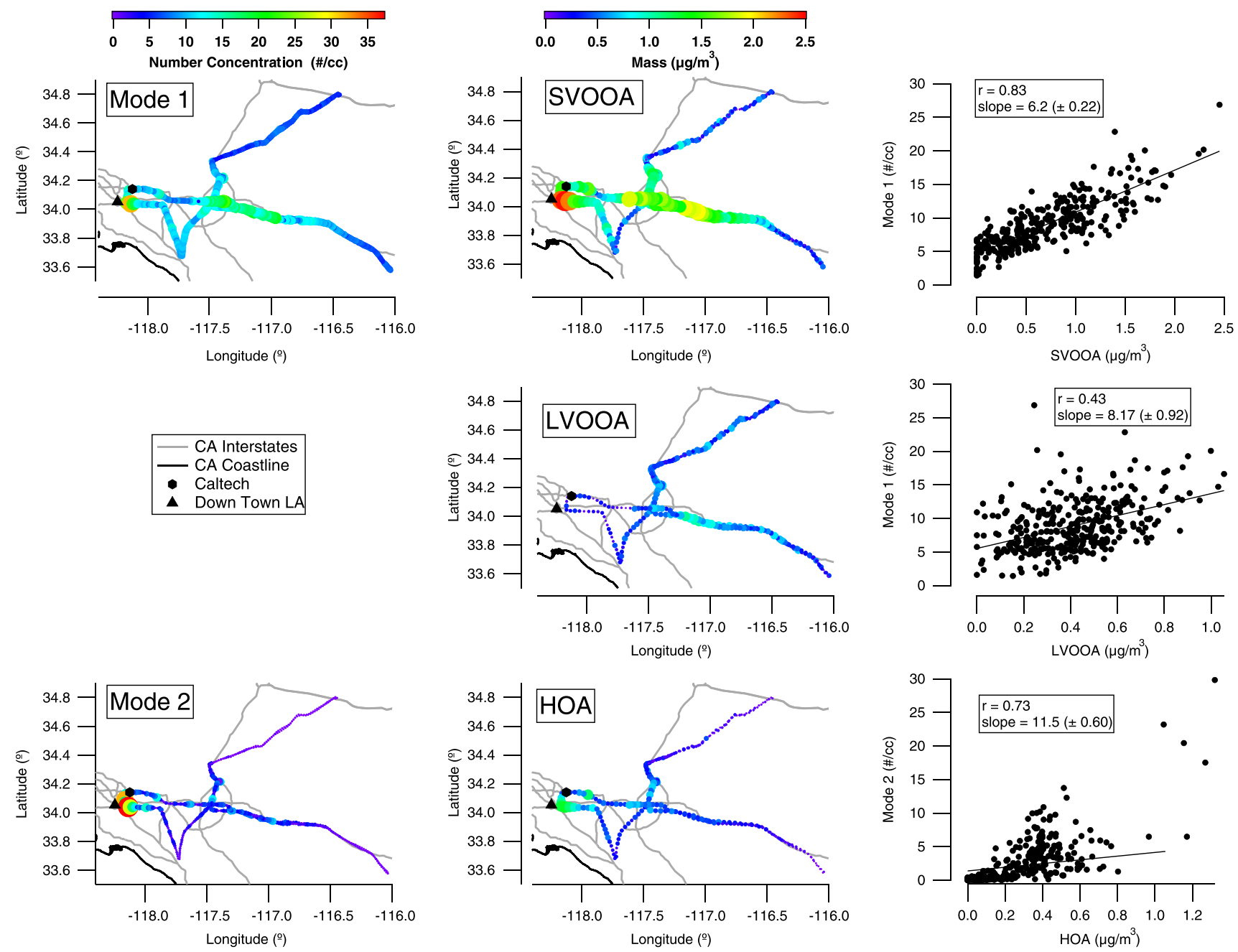

Figure 10. The flight maps of number concentration of mode 1 and mode 2 are plotted with the mass concentration of SVOOA, LVOOA, and HOA for 25 May. Mode 1 and mode 2 are colored and sized by number concentration, and SVOOA, LVOOA, and HOA are colored and sized by mass concentration. The scatter plot of mode 1 versus SVOOA, mode 1 versus LVOOA, and mode 2 versus HOA are also shown with the slope and $r$ value of the best fit line. Note that the PMF factors are colored by organic mass, whereas in Figure 8 they are colored by OA mass fraction.

aerosol with detectible scattering signals, mode 1 , which contained an $\mathrm{rBC}$ core diameter of $90-125 \mathrm{~nm}\left(d_{v e}\right)$ with a coating thickness diameter greater than $100 \mathrm{~nm}$, and mode 2 , which contained an $\mathrm{rBC}$ core diameter of $150-200 \mathrm{~nm}\left(d_{v e}\right)$ and a coating thickness diameter less than $100 \mathrm{~nm}$. These modes were chosen to represent thickly coated particles (mode 1) and thinly coated particles (mode 2). Because of the detection limits of the SP2, it was not possible to isolate thickly and thinly coated modes of particles with the same rBC core diameter. Flight maps highlighting mode 1 and mode 2 are shown alongside those for SVOOA, LVOOA, and HOA in Figure 10.

[29] On 25 May the two regions with the highest number concentrations of $\mathrm{rBC}$ with detectible scattering signals occurred in the region downwind of downtown LA and the Banning pass outflow. The number concentration of mode 2 particles was highest near downtown LA, indicating the dominance of thinly coated particles in the source-rich region of the basin. Mode 2 is relatively low in the rest of the basin. The number concentration of mode 1 is high downwind of downtown (although not as high as mode 2) and then again in the Banning pass outflow region. Mode 1 is the dominant mode in the outflow region. The downtown region contains high amounts of both modes, although the thinly coated $\mathrm{rBC}$ particles dominate, whereas in the outflow, the thickly coated $\mathrm{rBC}$ particles dominate.

[30] The correlation between mode 2 (relatively thinly coated particles) and HOA is $r=0.73$ (Figure 10). The highest mass concentration of HOA occurred downwind of downtown LA and was relatively low in other portions of the basin, behavior that is similar to that of mode 2 particles. SVOOA is compared to mode 1 particles in the top of Figure 10 and has a correlation of $r=0.83$. Similar to mode 1, SVOOA is high in both the region downwind of downtown LA and in the Banning outflow. Regions exist where SVOOA is high and mode 1 is not, i.e., the eastern basin, and this can be explained by aerosol measured by the AMS that did not contain an $\mathrm{rBC}$ core or from particles 
Table 4. Pearson's $r$ of SP2 Number Concentrations of Mode 1 and Mode 2 With Mass Concentrations of PMF Factors

\begin{tabular}{lcc}
\hline OA Type & Mode 1 & Mode 2 \\
\hline HOA & 0.67 & 0.73 \\
SVOOA & 0.83 & 0.68 \\
LVOOA & 0.43 & 0.16 \\
\hline
\end{tabular}

outside of the SP2 range. LVOOA is highest in the Banning outflow, and although its correlation with mode 1 is low $(r=0.43)$, LVOOA likely contributes to mode 1 particles in this region. Table 4 shows a summary of the correlations between the number concentration of modes 1 and 2 and the mass concentrations of HOA, SVOOA, and LVOOA for 25 May.

[31] The correlation with HOA and SVOOA with modes 2 and 1, respectively, links the mixing state information of the rBC-containing aerosol to the sources of organic that coat it. Well-characterized coatings may help interpret radiative absorption enhancement of coated black carbon discrepancies found in the laboratory versus that measured in the atmosphere [Cappa et al., 2012].

\section{Comparison to Other Campaigns}

[32] Some previous urban characterizations of OA are summarized in Table 1. The average atomic O:C ratio of the airborne OA sampled by the TO during the CalNex campaign is 0.31 ( \pm 0.09$)$, which is lower than those of the other LA area and Mexico City ground-based campaigns, SOAR, PACO, CalNex-LA, and MILAGRO. These campaigns reported average midday $\mathrm{O}: \mathrm{C}$ of 0.42 (PACO and SOAR), 0.41 (CalNex-LA), and 0.48 (MILAGRO). The average $\mathrm{O}: \mathrm{C}$ values during the TO flyover times only were 0.27 and 0.37 for airborne and ground-site AMS, respectively. Given the $30 \%$ uncertainty in $\mathrm{O}: \mathrm{C}$ reported by the high-resolution AMS [Aiken et al., 2007] and the uncertainty of the $f_{44}$ of the C-ToF-AMS, these O:C values are not deemed significantly different.

[33] The airborne average $\mathrm{OA}$ concentration measured by the TO during CalNex, $2.4 \mu \mathrm{g} / \mathrm{sm}^{3}$, was less than those measured in the two previous LA ground-based campaigns $\left(\mathrm{PACO}-3.2 \mu \mathrm{g} / \mathrm{sm}^{3}\right.$ and SOAR-19.9 $\left.\mu \mathrm{g} / \mathrm{sm}^{3}\right)$. Comparison of CalNex to the PACO campaign is especially appropriate since sampling for PACO measurements included the month of May, while SOAR measurements were made later in the summer. The difference between the ground and airborne OA mass concentrations during CalNex are consistent with comparable measurements in Mexico City. The average OA loading for the airborne and ground-based Mexico City MILAGRO campaign was $\sim 7$ times higher than the airborne average OA on the TO during CalNex. The range of airborne OA reported for the LONGREX and ADIENT Northern Europe campaign is twice that reported

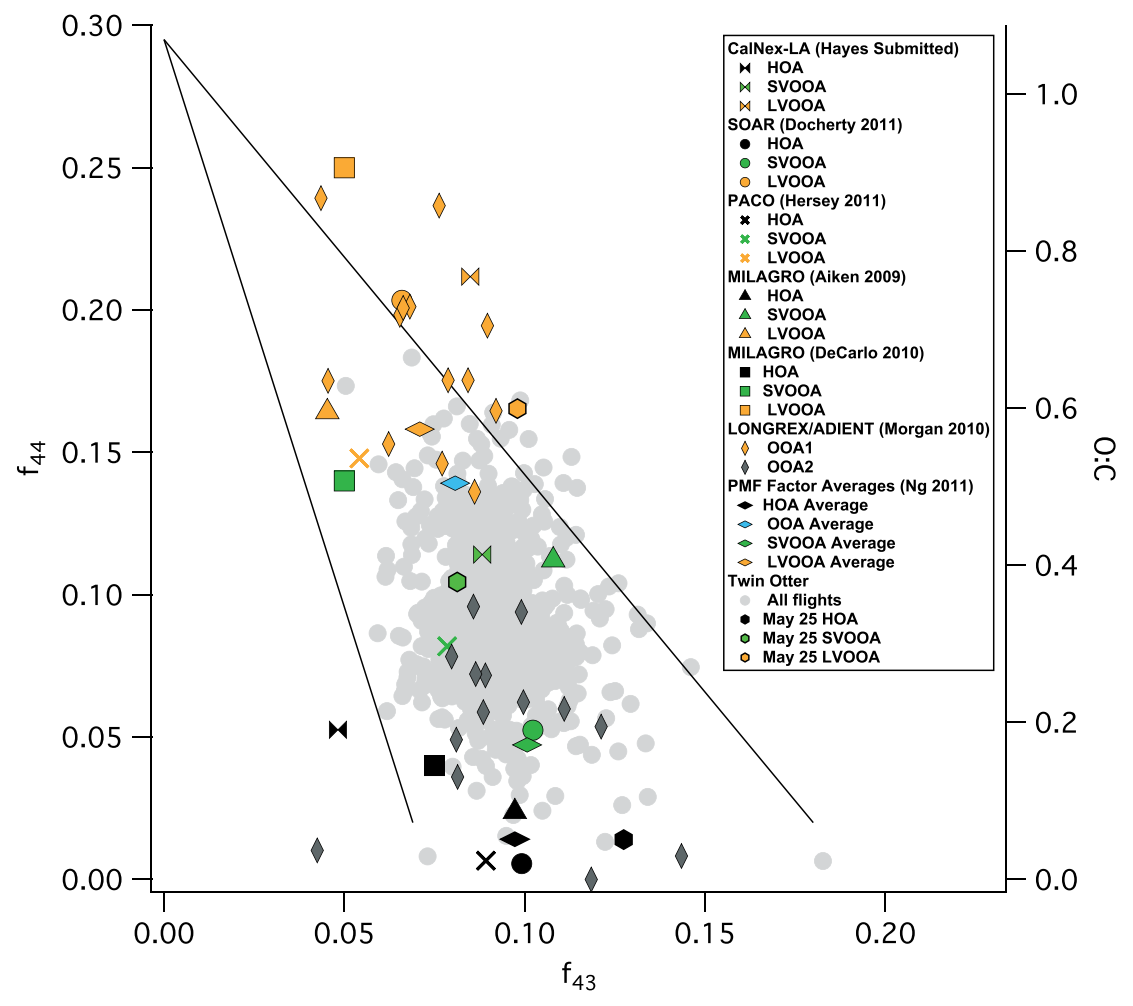

Figure 11. Fraction of OA at $m / z 44\left(f_{44}\right)$ versus the fraction of OA at $m / z 43\left(f_{43}\right)$ for the Twin Otter data (grey circular points). The three factors from the 25 May flight are shown as hexagon markers. The black, green, and orange markers are the HOA, SVOOA, and LVOOA from the CalNex-LA, SOAR, PACO, and MILAGRO ground-based campaigns, the PMF factor averages from $\mathrm{Ng}$ et al. [2011], and additionally the MILAGRO and LONGREX/ADIENT aircraft campaigns [DeCarlo et al., 2010; Morgan et al., 2010 ]. The O:C axis is based on equation (1). 
for the airborne CalNex. In summary, compared to other airborne and ground-based urban campaigns, the airborne OA concentrations in Los Angeles are among the lowest reported. PM 2.5 measurements taken at the North Main Street Los Angeles CARB monitoring station confirm that the days sampled during May 2010 were indeed relatively unpolluted (Figure 1).

[34] The final two columns of Table 1 list the average mass fraction for HOA and OOA for the various campaigns. The ground-based campaigns have $24 \mathrm{~h}$ and midday averages, and the aircraft data are averaged over the entire flight. The ground-based LA campaigns yielded average HOA fractions of $12 \%$ (Pasadena ground-site), $20 \%$ (SOAR), and 23\% (PACO). In Mexico City MILAGRO, the HOA fraction was reported to be $20 \%$ (airborne) and $29 \%$ (ground-based). The HOA fraction for the LONGREX and ADIENT campaigns exhibited a range of 5-20\%. The HOA fraction reported for the 25 May CalNex flight, 19\%, lies within the range of previously reported values. The OOA fraction for the 25 May CalNex flight, $81 \%$, is consistent with the LONGREX and ADIENT, SOAR, and PACO campaigns that report OOA fractions of $80-95 \%, 77.8 \%$, and $77 \%$, respectively. In the MILAGRO campaigns and at the CalNex Pasadena ground-site, lower OOA average fractions (ranging from $46 \%$ to $70 \%$ ) were found, as compared to the airborne CalNex measurements. The average midday OOA fraction for the ground-based campaigns, which is a more appropriate comparison for these aircraft data, range from approximately $70 \%$ to $90 \%$. Even with low OA mass loadings during May 2010, the fraction of submicron aerosol mass attributed to HOA and OOA based on the airborne measurements is consistent with that of previous LA area campaigns and those in Mexico City and Northern Europe.

[35] In most ambient data sets in the Northern Hemisphere, the dominant AMS OA mass spectral signals are $\mathrm{m} / \mathrm{z} 44$ and $\mathrm{m} / \mathrm{z}$ 43. The OA signals at $\mathrm{m} / \mathrm{z} 44$ and $\mathrm{m} / \mathrm{z} 43$ are mostly from the $\mathrm{CO}_{2}^{+}$ion (a tracer for carboxylic acid [Alfarra et al., 2004]) and the $\mathrm{C}_{2} \mathrm{H}_{3} \mathrm{O}^{+}$ion, respectively. Although the gas-phase $\mathrm{CO}_{2}$ contribution to the organic mass signal at $\mathrm{m} / \mathrm{z} 44$ can be significant at low OA loadings [Setyan et al., 2012], the gas-phase $\mathrm{CO}_{2}$ interference during the CalNex campaign was negligible. The $f_{44}$ versus $f_{43}$ space (Figure 11) provides a context for comparing the extent to which OA has undergone atmospheric processing [Ng et al., 2010]. The airborne CalNex HOA factor (black hexagon marker in Figure 11) has a similar $f_{44}$ as the PACO HOA, average HOA from $\mathrm{Ng}$ et al. [2011], and three of the LONGREX/ADIENT HOA flights, indicating a similarly low level of oxidation in the HOA between cities. The airborne CalNex SVOOA (green hexagon marker) lies near the middle of the range of SVOOA solutions and is closest to the SVOOA for PACO, CalNex-LA, and one of the LONGREX/ADIENT flights. The airborne CalNex LVOOA (orange hexagon marker) lies in the lower range of $f_{44}$ for the majority of the LVOOA solutions (MILAGRO, SOAR, and CalNex Pasadena ground-site), and several of the LONGREX/ADIENT results exhibit a higher $f_{44}$ contribution to the LVOOA solution. The relatively low $f_{44}$ in the LVOOA airborne CalNex PMF solution is a result of only modest photochemical processing and/or transport from sources before sampling.

\section{Conclusions}

[36] The May 2010 CalNex airborne Los Angeles OA mass concentration measurements reflect the meteorological conditions of that month that include a relatively deep boundary layer. Absolute levels are lower than those reported during previous LA area campaigns, MILAGRO, and in Northern Europe. Indeed, overall aerosol concentrations during May 2010 were among the lowest in the last decade. Despite these relatively clean conditions, observations regarding the spatial variability of oxidized mass in the LA Basin can still be made. Multiday buildup of emissions made spatial patterns difficult to discuss, whereas under "clean" conditions in which the PBL height is high, singleday pollution buildup and increase of $\mathrm{O}$ : $\mathrm{C}$ from west to east in the basin is observed.

[37] The increase in oxidation versus longitude was investigated further with PMF results from the 25 May flight, for which the highest variation in $\mathrm{O}: \mathrm{C}$ from west to east for one flight occurred. The ratio of $\mathrm{HOA} / \mathrm{rBC}$ remained nearly flat from west to east within the basin and into the outflows, suggesting the general absence of evaporation for HOA. Both SVOOA/rBC and LVOOA/rBC increased in the outflows, suggesting that SOA is being formed. The OOA in the basin has a weaker correlation with WSOM than with the OOA in the outflows, which could suggest that some of the freshly formed SOA in the LA Basin is not water soluble.

[38] The two optical modes with different coating thickness diameters identified using SP2 data correlate well with the HOA and SVOOA factors despite the small fraction of rBC particles with a detectable optical coating. The high correlation of mode 1 , particles with coating thickness diameter greater than $100 \mathrm{~nm}$, with SVOOA suggests that the thickly coated particles in the region downwind of downtown LA and in Banning pass are composed of freshly formed SOA. The presence of mode 1 particles and LVOOA in the Banning pass suggest that mode 1 may also be composed of highly oxygenated mass that originated in the basin. The high correlation of mode 2 , particles with coating thickness diameter less than $100 \mathrm{~nm}$, with HOA suggests that the relatively thinly coated particles in the region downwind of downtown LA are composed of HOA, which is co-emitted with rBC.

[39] Finally, the present study adds to a growing body of work characterizing urban aerosol levels in the world's megacities. The data obtained during CalNex 2010 will serve as an indispensable platform for atmospheric modeling of organic aerosol.

[40] Acknowledgments. This work was supported by NOAA grant NA09OAR4310128. The authors would like to acknowledge the Center for Interdisciplinary Remotely-Piloted Aircraft Studies (CIRPAS) crew at the Naval Postgraduate School in Monterey, California for their support during CalNex. The authors would also like to acknowledge B. L. Lefer for use of the PBLH data from the CalNex Pasadena ground-site and W. T. Morgan for the use of their data in Figure 11. P.L.H. and J.L.J. thank CARB 08319/11-305 and DOE (BER/ASR) DE-SC0006035/DE-FG02-11ER65293, as well as a CIRES Visiting Fellowship to P.L.H.

\section{References}

Aiken, A. C., P. F. DeCarlo, and J. L. Jimenez (2007), Elemental analysis of organic species with electron ionization high-resolution mass spectrometry, Anal. Chem., 79, 8350-8358.

Aiken, A. C., et al. (2008), O/C and OM/OC ratios of primary, secondary, and ambient organic aerosols with high-resolution time-of-flight aerosol mass spectrometry, Environ. Sci. Technol., 42(12), 4478-4485. 
Aiken, A. C., et al. (2009), Mexico City aerosol analysis during MILAGRO using high resolution aerosol mass spectrometry at the urban supersite (T0)-Part 1: Fine particle composition and organic source apportionment, Atmos. Chem. Phys., 9(17), 6633-6653.

Allan, J. D., et al. (2004), A generalised method for the extraction of chemically resolved mass spectra from Aerodyne aerosol mass spectrometer data, J. Aerosol Sci., 35(7), 909-922.

Alfarra, M. R., et al. (2004), Characterization of urban and rural organic particulate in the lower Fraser valley using two Aerodyne aerosol mass spectrometers, Atmos. Environ., 38, 5745-5758.

Angevine, W. M., L. Eddington, K. Durkee, C. Fairall, L. Bianco, and J. Brioude (2012), Meteorological model evaluation for CalNex 2010, Mon. Weather Rev., 140, 3885-3906.

Bahreini, R., et al. (2012a), Gasoline emissions dominate over diesel in formation of secondary organic aerosol mass, Geophys. Res. Lett., 39, L06805, doi:10.1029/2011GL050718.

Bahreini, R., et al. (2012b), Mass spectral analysis of organic aerosol formed downwind of the Deepwater Horizon oil spill: Field studies and laboratory confirmations, Environ. Sci. Technol., 46(15), 8025-8034.

Bahreini, R., E. J. Dunlea, B. M. Matthew, C. Simons, K. S. Docherty, P. F. DeCarlo, J. L. Jimenez, C. A. Brock, and A. M. Middlebrook (2008), Design and operation of a pressure-controlled inlet for airborne sampling with an aerodynamic aerosol lens, Environ. Sci. Technol., 42(6), 465-471.

Baumgardner, D., et al. (2012), Soot reference materials for instrument calibration and inter comparisons: A workshop summary with recommendations, Atmos. Meas. Tech., 5, 1869-1887.

Blumenthal, D. L., W. H. White, and T. B. Smith (1977), Anatomy of a Los Angeles smog episode: Pollutant transport in the daytime sea breeze regime, Atmos. Environ., 12(4), 893-907.

Brown, S. G., T. Lee, G. A. Norris, P. T. Roberts, J. L. Collett Jr, P. Paatero, and D. R. Worsnop (2012), Receptor modeling of near-roadway aerosol mass spectrometer data in Las Vegas, Nevada, with EPA PMF, Atmos. Chem. Phys., 12(1), 309-325.

Cahill, J. F., K. Suski, J. H. Seinfeld, R. A. Zaveri, and K. A. Prather (2012), The mixing state of carbonaceous aerosol particles in northern and southern California measured during CARES and CalNex 2010, Atmos. Chem. Phys., 12, 10,989-11,002.

Canagaratna, M. R., et al. (2007), Chemical and microphysical characterization of ambient aerosols with the aerodyne aerosol mass spectrometer, Mass Spectrom. Rev., 26(2), 185-222.

Cappa, C. D., X. Zhang, C. L. Loza, J. S. Craven, L. D. Yee, and J. H. Seinfeld (2013), Application of Statistical Oxidation Model (SOM) to secondary organic aerosol formation from photooxidation of $\mathrm{C} 12$ alkanes, Atmos. Chem. Phys., 13, 1591-1606.

Cappa, C. D., et al. (2012), Radiative absorption enhancements due to the mixing state of atmospheric black carbon, Science, 337, 1078-1081.

Collins, D. R., R. C. Flagan, and J. H. Seinfeld (2002), Improved inversion of scanning DMA data, Aerosol Sci. Technol., 36(1), 1-9.

de Gouw, J. A., and J. L. Jimenez (2009), Organic aerosols in the Earth's atmosphere, Environ. Sci. Technol., 43, 7614-7618.

DeCarlo, P. F., et al. (2006), Field-deployable, high-resolution, time-offlight aerosol mass spectrometer, Anal. Chem., 78, 8281-8289.

DeCarlo, P. F., et al. (2008), Fast airborne aerosol size and chemistry measurements above Mexico City and Central Mexico during the MILAGRO campaign, Atmos. Chem. Phys., 8(14), 4027-4048.

DeCarlo, P. F., et al. (2010), Investigation of the sources and processing of organic aerosol over the Central Mexican Plateau from aircraft measurements during MILAGRO, Atmos. Chem. Phys., 10(12), 5257-5280.

Docherty, K. S., et al. (2008), Apportionment of primary and secondary organic aerosols in southern California during the 2005 Study of Organic Aerosols in Riverside (SOAR-1), Environ. Sci. Technol., 42, 7655-7662.

Docherty, K. S., et al. (2011), The 2005 Study of Organic Aerosols at Riverside (SOAR-1): Instrumental intercomparisons and fine particle composition, Atmos. Chem. Phys., 11(23), 12,387-12,420.

Drewnick, F., et al. (2005), A new Time-of-Flight Aerosol Mass Spectrometer (TOF-AMS) - Instrument description and first field deployment, Aerosol Sci. Technol., 39(7), 637-658.

Duong, H. T., A. Sorooshian, J. S. Craven, S. P. Hersey, A. R. Metcalf, X. Zhang, R. J. Weber, H. Jonsson, R. C. Flagan, and J. H. Seinfeld (2011), Water-soluble organic aerosol in the Los Angeles Basin and outflow regions: Airborne and ground measurements during the 2010 CalNex field campaign, J. Geophys. Res., 116, D00V04, doi:10.1029/2011JD016674.

Dzepina, K., R. M. Volkamer, S. Madronich, P. Tulet, I. M. Ulbrich, Q Zhang, C. D. Cappa, P. J. Ziemann, and J. L. Jimenez (2009), Evaluation of recently-proposed secondary organic aerosol models for a case study in Mexico City, Atmos. Chem. Phys., 9, 5681-5709.

Dzepina, K., R. M. Volkamer, C. D. Cappa, S. Madronich, P. F. Decarlo, R. Z. Zaveri, and J. L. Jimenez (2011), Modeling the multiday evolution and aging of secondary organic aerosol During MILAGRO 2006, Environ. Sci. Technol., 45, 3496-3503.

Ensberg, J. J., et al. (2013), Inorganic and black carbon aerosols in the Los Angeles Basin during CalNex, J. Geophys. Res. Atmos., 118, 1777-1803, doi:10.1029/2012JD018136.

Gao, R. S., et al. (2007), A novel method for estimating light-scattering properties of soot aerosols using a modified single-particle soot photometer, Aerosol Sci. Technol., 41(2), 125-135.

Haagen-Smit, A. J. (1952), Chemistry and physiology of Los Angeles smog, Ind. Eng. Chem., 44(6), 1342-1346.

Haman, C. L., B. Lefer, and G. A. Morris (2012), Seasonal variability in the diurnal evolution of the boundary layer in a near coastal urban environment, J. Atmos. Oceanic Technol., 29, 697-710.

Hayes, P. L., et al. (2013), Organic aerosol composition and sources in Pasadena, California, during the 2010 CalNex campaign, J. Geophys. Res. Atmos., 118, 9233-9257, doi:10.1002/jgrd.50530.

Hegg, D. A., D. S. Covert, H. Jonsson, and P. A. Covert (2005), Determination of the transmission efficiency of an aircrfact aerosol inlet, Aerosol Sci. Technol., 39(10), 966-971.

Hersey, S. P., J. S. Craven, K. A. Schilling, A. R. Metcalf, A. Sorooshian, M. N. Chan, R. C. Flagan, and J. H. Seinfeld (2011), The Pasadena Aerosol Characterization Observatory (PACO): Chemical and physical analysis of the Western Los Angeles Basin aerosol, Atmos. Chem. Phys., 11(15), 7417-7443.

Hersey, S. P., et al. (2013), Composition and hygroscopicity of the Los Angeles Aerosol: CalNex, J. Geophys. Res. Atmos., 118, 3016-3036, doi:10.1002/jgrd.50307.

Jayne, J. T., D. C. Leard, X. Zhang, P. Davidovits, K. A. Smith, C. E. Kolb, and D. R. Worsnop (2000), Development of an aerosol mass spectrometer for size and composition analysis of submicron particles, Aerosol Sci. Technol., 33, 49-79.

Jimenez, J. L., et al. (2009), Evolution of organic aerosols in the atmosphere, Science, 326(5959), 1525-1529.

Kondo, Y., Y. Miyazaki, N. Takegawa, T. Miyakawa, R. J. Weber, J. L. Jimenez, Q. Zhang, and D. R. Worsnop (2007), Oxygenated and watersoluble organic aerosols in Tokyo, J. Geophys. Res., 112, D01203, doi:10.1029/2006JD007056.

Kroll, J. H., et al. (2011), Carbon oxidation state as a metric for describing the chemistry of atmospheric organic aerosol, Nat. Chem., 3(2), 133-139.

Laborde, M., P. Mertes, P. Zieger, J. Dommen, U. Baltensperger, and M. Gysel (2012), Sensitivity of the single particle soot photometer to different black carbon types, Atmos. Meas. Tech., 5, 1031-1043.

Lanz, V. A., M. R. Alfarra, U. Baltensperger, B. Buchmann, C. Hueglin, and A. S. H. Prévôt (2007), Source apportionment of submicron organic aerosols at an urban site by factor analytical modelling of aerosol mass spectra, Atmos. Chem. Phys., 7(6), 1503-1522.

Metcalf, A. R., J. S. Craven, J. J. Ensberg, A. Sorooshian, H. T. Duong, H. H. Jonsson, R. C. Flagan, and J. H. Seinfeld (2012), Black carbon aerosol over the Los Angeles Basin during CalNex, J. Geophys. Res. 117, D00V13, doi:10.1029/2011JD017255.

Middlebrook, A. M., R. Bahreini, J. L. Jimenez, and M. R. Canagaratna (2012), Evaluation of composition-dependent collection efficiencies for the Aerodyne Aerosol Mass Spectrometer using field data, Aerosol Sci. Technol., 46(3), 258-271.

Morgan, W. T., J. D. Allan, K. N. Bower, E. J. Highwood, D. Liu, G. R. McMeeking, M. J. Northway, P. I. Williams, R. Krejci, and H. Coe (2010), Airborne measurements of the spatial distribution of aerosol chemical composition across Europe and evolution of the organic fraction, Atmos. Chem. Phys., 10(8), 4065-4083.

$\mathrm{Ng}$, N. L., et al. (2010), Organic aerosol components observed in Northern Hemispheric datasets from aerosol mass spectrometry, Atmos. Chem. Phys., 10(10), 4625-4641.

Ng, N. L., M. R. Canagaratna, J. L. Jimenez, Q. Zhang, I. M. Ulbrich, and D. R. Worsnop (2011), Real-time methods for estimating organic component mass concentrations from aerosol mass spectrometer data, Environ. Sci. Technol., 45(3), 910-916.

Paatero, P., and U. Tapper (1994), Positive matrix factorization-A nonnegative factor model with optimal utilization of error-estimates of data values, Environmetrics, 5(2), 111-126.

Robinson, A. L., N. M. Donahue, M. K. Shrivastava, E. A. Weitkamp, A. M. Sage, A. P. Grieshop, T. E. Lane, J. R. Pierce, and S. N. Pandis (2007), Rethinking organic aerosols: Semivolatile emissions and photochemical aging, Science, 315(5816), 1259-1262.

Rudich, Y., N. M. Donahue, and T. F. Mentel (2007), Aging of organic aerosol: Bridging the gap between laboratory and field studies, Annu. Rev. Phys. Chem., 58, 321-352. 


\section{CRAVEN ET AL.: LA BASIN AIRBORNE ORGANIC AEROSOL}

Ryerson, T. B., et al. (2013), The 2010 California research at the Nexus of air quality and climate change (CalNex) field study, J. Geophys. Res. Atmos., 118, 5830-5866, doi:10.1002/jgrd.50331.

Setyan, A., et al. (2012), Characterization of submicron particles influenced by mixed biogenic and anthropogenic emissions using high-resolution aerosol mass spectrometry: Results from CARES, Atmos. Chem. Phys., $12,8131-8156$.

Sullivan, A. P., R. E. Peltier, C. A. Brock, J. A. de Gouw, J. S. Halloway, C. Warneke, A. G. Wollny, and R. J. Weber (2006), Airborne measurements of carbonaceous aerosol soluble in water over northeastern United States: Method development and an investigation into water-soluble organic carbon sources, J. Geophys. Res., 111, D23S46, doi:10.1029/2006JD007072.

Ulbrich, I. M., M. R. Canagaratna, Q. Zhang, D. R. Worsnop, and J. L. Jimenez (2009), Interpretation of organic components from positive matrix factorization of aerosol mass spectrometric data, Atmos. Chem. Phys., 9(9), 2891-2918.

Warneke, C., J. A. de Gouw, J. S. Holloway, J. Peischl, T. B. Ryerson, E. Atlas, D. Blake, M. Trainer, and D. D. Parrish (2012), Multiyear trends in volatile organic compounds in Los Angeles, California: Five decades of decreasing emissions, J. Geophys. Res., 117, D00V17, doi:10.1029/2012JD017899.

Zhang, Q., et al. (2007), Ubiquity and dominance of oxygenated species in organic aerosols in anthropogenically-influenced Northern Hemisphere midlatitudes, Geophys. Res. Lett., 34, L13801, doi:10.1029/2007GL029979.

Zhang, Q., J. L. Jimenez, M. R. Canagaratna, I. M. Ulbrich, N. L. Ng, D. R. Worsnop, and Y. Sun (2011), Understanding atmospheric organic aerosols via factor analysis of aerosol mass spectrometry: A review, Anal. Bioanal. Chem., 401(10), 3045-3067. 